\title{
New Role for L-Arginine in Regulation of Inducible Nitric-Oxide-Synthase-Derived Superoxide Anion Production in Raw 264.7 Macrophages
}

Michaela Pekarova, ${ }^{1}$ Antonin Lojek, ${ }^{1}$ Hana Martiskova, ${ }^{1,2}$ Ondrej Vasicek, ${ }^{1}$ Lucia Bino, ${ }^{1}$ A. Klinke, ${ }^{3}$ D. Lau, ${ }^{3}$ Radek Kuchta, ${ }^{4}$ Jaroslav Kadlec, ${ }^{4}$ Radimir Vrba, ${ }^{4}$ and Lukas Kubala ${ }^{1}$

${ }^{1}$ Institute of Biophysics, The Academy of Sciences of the Czech Republic, Kralovopolska 135, 61265 Brno, Czech Republic

${ }^{2}$ Department of Biochemistry, Faculty of Science, Masaryk University, Kotlarska 267/2, 61137 Brno, Czech Republic

${ }^{3}$ Department of Cardiology, Hamburg University Heart Center, Martinistrasse 52, 20246 Hamburg, Germany

${ }^{4}$ Faculty of Electrical Engineering and Communication, Brno University of Technology, Technicka 3058/10, 61600 Brno, Czech Republic

Received 9 September 2011; Accepted 7 November 2011

Academic Editor: Marco Antonio Cassatella

Dietary supplementation with L-arginine was shown to improve immune responses in various inflammatory models. However, the molecular mechanisms underlying L-arginine effects on immune cells remain unrecognized. Herein, we tested the hypothesis that a limitation of $L$ arginine could lead to the uncoupled state of murine macrophage inducible nitric oxide synthase and, therefore, increase inducible nitric-oxide-synthase-derived superoxide anion formation. Importantly, we demonstrated that L-arginine dose- and time dependently potentiated superoxide anion production in bacterial endotoxin-stimulated macrophages, although it did not influence NADPH oxidase expression and activity. Detailed analysis of macrophage activation showed the time dependence between LPS-induced iNOS expression and increased $\mathrm{O}_{2}{ }^{--}$formation. Moreover, downregulation of macrophage iNOS expression, as well as the inhibition of iNOS activity by NOS inhibitors, unveiled an important role of this enzyme in controlling $\mathrm{O}_{2}{ }^{\bullet-}$ and peroxynitrite formation during macrophage stimulation. In conclusion, our data demonstrated that simultaneous induction of NADPH oxidase, together with the iNOS enzyme, can result in the uncoupled state of iNOS resulting in the production of functionally important levels of $\mathrm{O}_{2}{ }^{\bullet-}$ soon after macrophage activation with LPS. Moreover, we demonstrated, for the first time that increased concentrations of L-arginine further potentiate iNOS-dependent $\mathrm{O}_{2}{ }^{\bullet-}$ formation in inflammatory macrophages.

KEYWORDS: Macrophages, L-arginine, inducible nitric oxide synthase, superoxide anion, NO. 


\section{INTRODUCTION}

The innate immune system provides the first-line defense against injurious insults. Beside its beneficial role in organism defense, deregulation of innate immune responses is implicated in the pathogenesis of various chronic diseases, including congestive heart failure, type 2 diabetes, and associated complications such as dyslipidemia and artherosclerosis [1-4]. These pathological conditions are believed to be tightly associated with an increased and long-termed synthesis of reactive oxygen (ROS) and reactive nitrogen species (NO; superoxide anion $\mathrm{O}_{2}{ }^{\bullet-}$; hydrogen peroxide, $\mathrm{H}_{2} \mathrm{O}_{2}$; and peroxynitrite, $\mathrm{ONOO}^{-}$, etc.) by activated monocytes and macrophages. Particularly ROS are suggested to be responsible for the oxidation of a wide array of molecules in cells, including DNA and proteins that can promote pathological changes in arteries $[1,3,4]$.

$\mathrm{O}_{2}{ }^{\bullet-}$ is the first ROS produced by macrophages upon their contact with a variety of activating stimuli (e.g., LPS, cytokines, growth factors, and fragments of bacterial membranes) [5]. The significant source of $\mathrm{O}_{2}{ }^{\bullet-}$ in phagosomes during the first hours after stimulation was shown to be the macrophage NADPH oxidase enzyme complex $[6,7]$. Another crucial reactive intermediate that is critically involved in the antimicrobial and antitumor activities of macrophages is NO [8]. It is biosynthesized by nitric oxide synthase (NOS) from L-arginine in macrophages activated by proinflammatory stimuli like IFN$\gamma$, TNF, and LPS [8-10]. The enzyme functions as a dimer consisting of two identical monomers, which can be functionally (and structurally) divided into two major domains: a C-terminal reductase domain and an N-terminal oxygenase domain. Inducible NOS (iNOS) has been described as calciuminsensitive and dependent on the binding of different cofactors like NADPH, flavin adenine dinucleotide, flavin mononuleotide, heme, tetrahydrobiopterine $\left(\mathrm{BH}_{4}\right)$, and calmodulin [11-13]. Interestingly, it was shown previously that, in the absence of L-arginine or NOS cofactors, iNOS isolated from macrophages becomes uncoupled $[14,15]$. The uncoupled state of NOS was described when electrons flowing from the reductase domain to the heme are diverted to molecular oxygen instead of to L-arginine, resulting in the formation of $\mathrm{O}_{2}{ }^{\bullet-}$ [16]. These facts suggest that simultaneous production $\mathrm{of}_{2} \mathrm{O}^{\bullet-}$ (by NADPH oxidase and iNOS enzyme) and NO (by iNOS enzyme) can lead to increased $\mathrm{O}_{2}{ }^{\bullet-}$ as well as $\mathrm{ONOO}^{-}$ formation. $\mathrm{ONOO}^{-}$, a short-lived oxidant and potent inducer of cell death, is believed to be responsible for the progress of vascular diseases, ischaemia-reperfusion injury, circulatory shock, and inflammation $[1,2,5]$.

L-arginine is an abundant amino acid in body fluids which is not toxic to cells [17]. Importantly, it was previously demonstrated that L-arginine has a unique role in the maintenance of immune homeostasis $[18,19]$. It was found that it is crucially involved in the regulation of T-cell and macrophage functions [2022] and according to different clinical studies, it is now suggested that L-arginine supplementation may be of clinical benefit in improving wound healing and immune responses in humans [23, 24]. Since, L-arginine is now recognized as influencing the relationships between innate and acquired immune responses, we tested the hypothesis that a limitation of L-arginine could lead to the uncoupled state of iNOS and, therefore, increase iNOS-derived $\mathrm{O}_{2}{ }^{\bullet-}$ formation. The goal was to describe, in greater detail, the effect of various concentrations of L-arginine on the kinetic of $\mathrm{O}_{2}{ }^{--}$and $\mathrm{NO}$ production and to find the possible connection between iNOS protein expression and activity and $\mathrm{O}_{2}{ }^{\bullet-}$ production in inflammatory macrophages.

\section{MATERIAL AND METHODS}

\subsection{Cell Culture}

Unless otherwise stated, all chemicals were purchased from Sigma-Aldrich (USA). The murine RAW 264.7 macrophage cell line was obtained from the American Type Culture Collection (ATCC, USA) and was grown in Dulbecco's modified Eagle's media (PAA, Pasching, Austria) supplemented with 10\% fetal bovine serum (FBS, low endotoxin; PAA, Pasching, Austria) and $1 \%$ gentamycin. Cells were stimulated with $50 \mathrm{ng} / \mathrm{mL}$ of LPS (Escherichia coli serotype 026:B6). 
For the evaluation of the effect of extracellular L-arginine availability, L-arginine-free DMEM media was used for the experiments. DMEM media was supplemented with different concentrations of L-arginine: $100,200,300$, and $400 \mu \mathrm{M}$, which were chosen according to a few criteria. First, we selected doses that were comparable with reference mammalian plasma values for L-arginine ( 36-140 $\mu \mathrm{M})$ [25], and the highest concentration of L-arginine $(400 \mu \mathrm{M})$ was comparable with its content in commercially available DMEM media commonly used for in vitro experiments.

The following NOS inhibitors were employed: $N$-nitro-L-arginine methyl ester (L-NAME; final concentration $25 \mu \mathrm{M}$ ), 2-amino-5,6-dihydro-6-methyl-4H-1,3-thiazine (AMT; final concentration $10 \mu \mathrm{M}$ ), aminoguanidine (AG; final concentration $10 \mu \mathrm{M}$ ), and L-N6-(1-iminoethyl) lysine (LYS; final concentration $10 \mu \mathrm{M})$.

\subsection{Cell Viability}

The viability of cells was tested based on the total cellular mass of the adherent cells, using detergentcompatible protein assay reagent (Bio-Rad Laboratories, USA), with bovine serum albumin as a standard, as described previously [26]. None of the studied drugs was toxic for RAW 264.7 in the concentrations applied (data not shown).

\subsection{Intracellular L-Arginine Concentration}

Intracellular L-arginine was determined using a validated high-throughput liquid chromatography-tandem mass spectrometry (LC-MS/MS) assay, described in details elsewhere [27]. Cells were treated in DMEM media without L-arginine or with $400 \mu \mathrm{M}$ of L-arginine in the absence or presence of LPS $(50 \mathrm{ng} / \mathrm{mL})$ for $24 \mathrm{~h}$.

\subsection{Western Blot Analysis of iNOS}

After the treatment procedure, the RAW 264.7 cells were lysed using SDS-lysing buffer. The same amount of protein $(30 \mu \mathrm{g})$ from each lysate was subjected to SDS-polyacrylamide gel electrophoresis, as described previously [28]. After electrophoresis, the proteins were transferred to a PVDF (Immobilon-P) membrane and then incubated with a mouse iNOS-specific antibody (1/5000) (Anti-iNOS/NOS Type II $\mathrm{mAb}$, Transduction Laboratories, USA) for $24 \mathrm{~h}$, and with horseradish peroxidase-labelled anti-mouse IgG antibody (1/2000) (ECL Anti-mouse IgG, Biosciences, USA) for $1 \mathrm{~h}$. The equal loading of proteins was verified by $\beta$-actin immunoblotting (1/5000, SantaCruz Biotechnology, USA). The blots were visualized using SuperSignal West Pico Chemiluminescent Substrate (Pierce, USA) and exposed to CP-B X-ray films (Agfa, Czech Republic). The relative levels of the proteins were quantified by scanning densitometry, using the ImageJ program, and the individual band density value was expressed in arbitrary units.

\subsection{Determination of Nitrites}

NO production was determined based on the accumulation of NO oxidation product nitrites. Nitrite accumulation in cell culture media was determined by Griess method, using sodium nitrite as a standard, as described previously [29].

\subsection{Cytochrome c Reduction Assay}

The extracellular production of $\mathrm{O}_{2}{ }^{\bullet-}$ in macrophages was determined via spectrophotometric analysis of cytochrome c reduction as described in details previously [30]. The concentration of superoxide was calculated using the extinction coefficient of reduced cytochrome $\mathrm{c}$. 


\subsection{Determination of NADPH Oxidase Activity}

The NADPH oxidase activity was determined in cell lysates prepared according to the well-established protocol [31]. Briefly, to the $100 \mu \mathrm{L}$ of tested solution, lucigenin was added at final concentration $5 \mu \mathrm{M}$. After that, NADPH at final concentration $100 \mu \mathrm{M}$ was added to start the production of $\mathrm{O}_{2}{ }^{\bullet-}$. The luminescence signal was measured for $1 \mathrm{~h}$.

\subsection{Detection of NOX2, p47phox, and p67phox Expression by Quantitative RT-PCR}

Total RNA was isolated from RAW 264.7 cells with TRIZOL solution (TRI Reagent RT, MRC, USA), according to the supplier's instructions. RNA $(1 \mu \mathrm{g})$ was reverse transcribed to cDNA according to the manufacturer's instructions (DyNAmo cDNA Synthesis Kit, Finnzymes, Finland). The primers and probe no. 20 for NOX2, p67phox, and p47phox were designed using the Universal Probe Library (Roche, Switzerland). The sequence of primers was as follows: NOX2 (forward $5^{\prime}$-gtgcacagcaaagtgattgg- $3^{\prime}$, reverse $5^{\prime}$-tgccaacttcctcagctaca- $3^{\prime}$ ), p47phox (forvard $5^{\prime}$-ctgccacttaaccaggaacat-3', reverse $5^{\prime}$-ggacaccttcattcgccata$3^{\prime}$ ), and p67phox (forvard $5^{\prime}$-ccagccattcttcattcaca- $3^{\prime}$, reverse $5^{\prime}$-cccaggtggtagcaatcttc- $3^{\prime}$ ). Real-time PCR was performed on RTCykler7300 (Applied Biosystems), and the parameters of amplification were set up according to the supplier's instructions. The fold of the mRNA induction was calculated using the ${ }^{\Delta}{ }^{\Delta} C_{t}$ method, with GAPDH as a housekeeping gene (TaqMan Rodent GAPDH Control reagent, Applied Biosystems, USA) [31].

\subsection{Transfection of RAW 264.7 Cells}

Using an electroporation system (Gene Pulser II, Bio-Rad laboratopries, USA, for details see [31]), cells were transfected with plasmids containing the shRNA construct, against iNOS and negative control plasmid with a scrambled sequence (Origene, USA). Stably transfected cells were grown in DMEM + 5\% FBS and $5 \mu \mathrm{g} / \mathrm{mL}$ puromycin. RAW 264.7 cells transfected with both shRNA and negative control plasmid were sensitive to LPS stimulation. In the case of LPS-activated RAW 264.7 cells transfected with negative control plasmid, the expression of iNOS protein, nitrite accumulation, and $\mathrm{O}_{2}{ }^{\bullet-}$ production were comparable with those measured for nontransfected LPS-activated RAW 264.7 cells (data not shown).

\subsection{Luminol-Enhanced Chemiluminescence (CL) Determination of Oxidative Burst}

The CL of macrophages was measured using a microplate luminometer LM-01T (Immunotech, Czech Republic), as described previously [32]. Briefly, the reaction mixture consisted of $100 \mu \mathrm{L}$ of cells $(100 \times$ $10^{5}$ ), $1 \mathrm{mM}$ luminal, and one of the oxidative burst activators (PMA, $97.6 \mu \mathrm{g} / \mathrm{mL}$ or opsonized zymosan particles (OZP), $0.4 \mathrm{mg} / \mathrm{mL}$ ). Spontaneous CL measurements in samples containing the macrophages and all other substances, but none of the activators, were included in each assay. The CL emission was followed for $2 \mathrm{~h}$ at $37^{\circ} \mathrm{C}$. The integral value of the CL reaction represents the total ROS production by macrophages.

\subsection{Immunocytochemistry}

This method was used for the evaluation of $\mathrm{NO}$ - and $\mathrm{O}_{2}{ }^{\bullet-}$-derived $\mathrm{ONOO}^{-}$, which is known to react with tyrosine residues on proteins and yields a specific nitration product, nitrotyrosine [14]. Briefly, after treatment on 98-well plates (PAA), cells were fixed with $4 \%$ of paraformaldehyde in PBS at room temperature for $30 \mathrm{~min}$. Cells were then incubated with mouse monoclonal antinitrotyrosine $\operatorname{IgG}(1: 500$, Upstate Biotechnology, USA) for $1 \mathrm{~h}$. The immunostaining was accomplished with an Extravidin peroxidase staining kit using 3-amino-9-ethylcarbazole as a chromogen. The cells were then photographed under a light microscope at $\times 200$ magnification. 


\subsection{Detection of Scavenging Properties of Drugs against NO}

The potential ability of drugs to scavenge NO in chemical systems was tested by the electrochemical measurement of NO, as described previously [28]. The scavenging properties of the tested drugs are represented as a very rapid decrease in NO-induced signal detected by electrode connected to ISO NO MARK II potentiostat (WPI, USA). The integral area under the resulting curve corresponded to the total amount of NO present in the glass vial and was used for the evaluation of scavenging properties of the tested drugs. The scavenging properties of the drugs and chemicals against NO were not significant (data not shown).

\subsection{Data Analysis}

Data were statistically analyzed using a one-way analysis of variance (ANOVA), which was followed by Dunnett's multiple comparison test (Statistica for Windows 8.0, Statsoft, Tulsa, Okla, USA). All data are reported as means \pm SEM. A $P$ value of less than 0.05 was considered significant.

\section{RESULTS}

\subsection{L-Arginine-Enhanced Production of $\mathrm{O}_{2}{ }^{\bullet-}$ in RAW 264.7 Macrophages Stimulated with LPS}

In the first set of experiments, we tested the established hypothesis that a limitation of L-arginine availability could lead to the uncoupled state of iNOS and, therefore, increase iNOS-derived $\mathrm{O}_{2}{ }^{\bullet-}$ formation. Surprisingly, we found that, during the time of RAW 264.7 cells incubation with LPS, L-arginine, in all concentrations used (100-400 $\mu \mathrm{M})$, caused a marked dose- and time-dependent increase in $\mathrm{O}_{2}{ }^{\bullet-}$ formation, which started to rise after $12 \mathrm{~h}$ of cell incubation with LPS (Figure 1). In comparison to RAW 264.7 cells incubated in DMEM without L-arginine supplementation, the intracellular concentration of L-arginine was significantly increased after $24 \mathrm{~h}$ of cell treatment with $400 \mu \mathrm{M}$ of L-arginine $(38.91 \pm 3.18 \mu \mathrm{M}$ and $71.50 \pm 3.25 \mu \mathrm{M}^{*}$, mean $\pm \mathrm{SEM}$ ), as was determined by the specific LC-MS/MS method.

\subsection{Time-Dependent Induction of iNOS Protein, NO Production, and $\mathrm{O}_{2}{ }^{\bullet-}$ Formation in LPS-Stimulated RAW 264.7 Cells}

The marked increase in $\mathrm{O}_{2}{ }^{\bullet-}$ production in LPS-stimulated macrophages led to questions regarding the origin of the $\mathrm{O}_{2}{ }^{\bullet-}$ that was produced during the experiments. Therefore, we measured the iNOS protein expression, nitrite accumulation, and also the $\mathrm{O}_{2}{ }^{\bullet-}$ formation during a time period of $24 \mathrm{~h}$ after LPS stimulation of macrophages cultivated in DMEM media with $400 \mu \mathrm{M}$ of L-arginine. As expected, incubation of RAW 264.7 cells with LPS resulted in a time-dependent accumulation of nitrites and expression of iNOS protein (Figure 2(a)). The expression of iNOS started approximately $4 \mathrm{~h}$ after the RAW 264.7 cells were stimulated with LPS and was followed by a gradual nitrite accumulation in cell supernatants (Figure 2(a)). iNOS expression reached its maximum levels $6 \mathrm{~h}$ after LPS administration and then remained stable till the end of the experiment. Interestingly, detailed analysis showed that incubation of RAW 264.7 cells with LPS also resulted in a time-dependent production of $\mathrm{O}_{2}{ }^{\bullet-}$, which started to rise early (approx., $3 \mathrm{~h}$ after LPS administration) and was stable for the next few hours. Then we observed a massive increase in $\mathrm{O}_{2}{ }^{\bullet-}$ formation (Figure 2(a)). The protein concentration of the total cellular mass had not significantly changed in any of the experimental groups, in comparison with the control cells. This indicates that none of the studied drugs was toxic for RAW 264.7 in the concentrations applied (data not shown).

\subsection{L-Arginine-Enhanced Production of $\mathrm{O}_{2}{ }^{\bullet-}$ Was Not Associated with Changes in NADPH Oxidase Expression and Activity}

Since NADPH oxidase is known to be the principal source of $\mathrm{O}_{2}{ }^{\bullet-}$ in activated phagocytes, we determined whether the changes in $\mathrm{O}_{2}{ }^{\bullet-}$ production observed during the time of macrophage activation were associated 

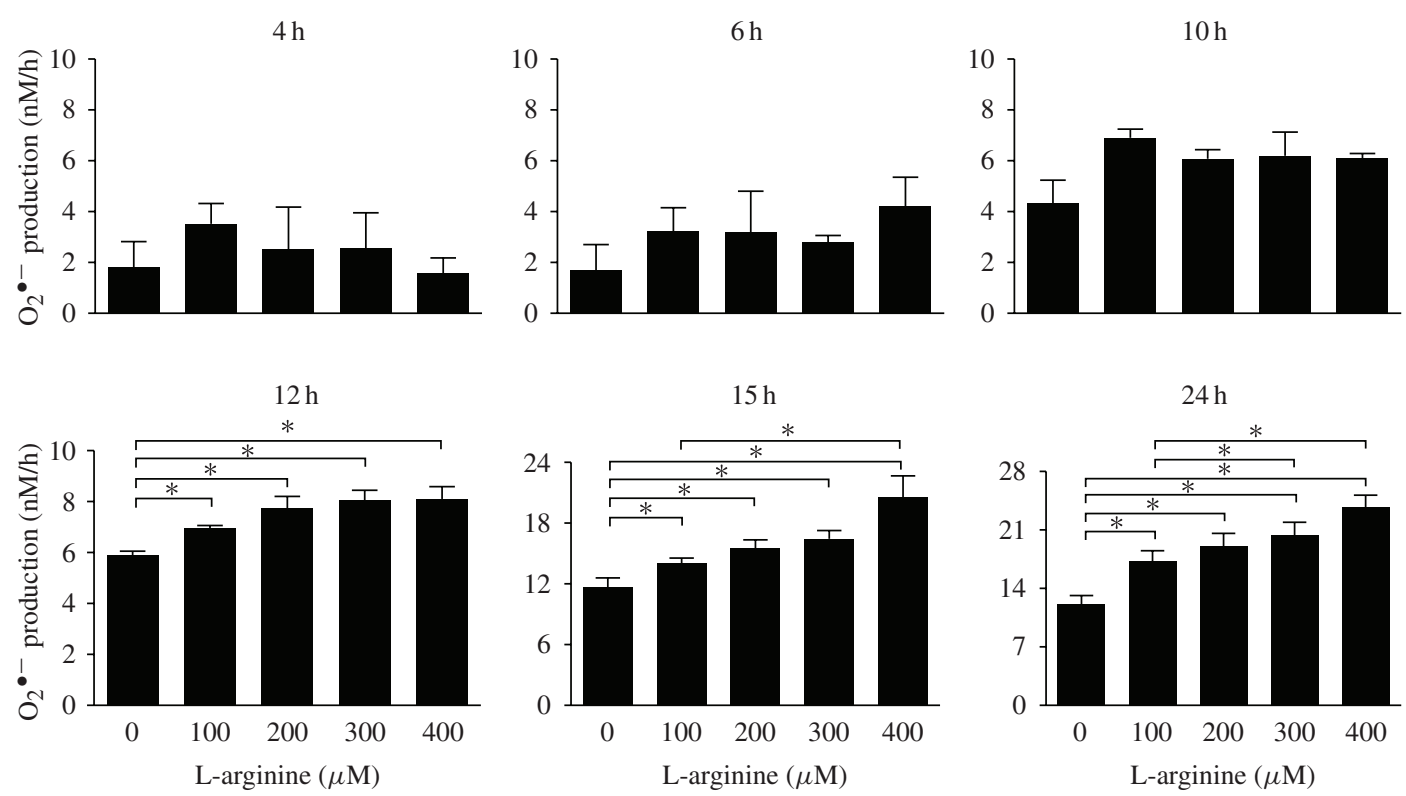

FIGURE 1: L-arginine dose- and time-dependently regulated $\mathrm{O}_{2}{ }^{\bullet-}$ production in LPS-stimulated RAW 264.7 cells. Cells were incubated in L-arginine-free DMEM or DMEM with different concentrations of L-arginine $(100,200,300$, and $400 \mu \mathrm{M})$ and stimulated with LPS $(50 \mathrm{ng} / \mathrm{mL})$. The $\mathrm{O}_{2}{ }^{\bullet-}$ was determined in the cell culture supernatants in indicated times after LPS administration using cytochrome c. Results represent means $\pm \operatorname{SEM}(n=6) .{ }^{*} P<0.05$.

with an increased expression of the selected NADPH oxidase subunits. Using the quantitative RT-PCR method, we showed that LPS significantly increased only the mRNA levels of the NOX2 membraneassociated complex (Figure 2(b)), with the levels of cytosolic p47 and p67 subunits remaining unaffected (Figure 2(b)). Importantly, extracellular L-arginine supplementation did not change the mRNA levels of all subunits in nonstimulated and LPS-stimulated RAW 264.7 cells (Figure 2(b)). To study the activity of NADPH oxidase in macrophages and cell lysates, we used two known activators of oxidative burst, PMA and OZP. We found that the PMA- and OZP-induced $\mathrm{O}_{2}{ }^{\bullet-}$ formation was not affected by L-arginine in the concentrations applied $(0-400 \mu \mathrm{M})$ (data not shown).

\subsection{L-Arginine-Enhanced Production of $\mathrm{O}_{2}{ }^{\bullet-}$ Was Dependent on iNOS Expression in RAW 264.7 Macrophages}

To further define the role of iNOS enzyme in the regulation of L-arginine-dependent $\mathrm{O}_{2}{ }^{\bullet-}$ production, we established stabile RAW 264.7 cell clones transfected with shRNA against iNOS (iNOS ${ }^{-/}$RAW 264.7 cells). In contrast to LPS-stimulated RAW 264.7, successfully transfected iNOS ${ }^{-/-}$RAW 264.7 cells were characterized by downregulated iNOS protein expression (Figure 3(a)). Correspondingly, the nitrite accumulation in RAW 264.7 cell supernatants was significantly higher after 24-hour stimulation with LPS, in comparison with the basal level of nitrites in nonstimulated RAW 264.7, while no such increase was observed in iNOS ${ }^{-/-}$RAW 264.7 cell supernatants. Interestingly, a similar effect was determined for $\mathrm{O}_{2}{ }^{\bullet-}$ production, which was significantly reduced in iNOS ${ }^{-/-}$RAW 264.7 cells stimulated with LPS (Figure 3(b)).

Further, we analyzed whether the NADPH oxidase activity in NOS $^{-/-}$RAW 264.7 cells can be affected by the downregulation of iNOS protein expression. We used PMA and OZP for activation of nonstimulated and LPS-stimulated macrophages in the presence of $400 \mu \mathrm{M}$ L-arginine. We found that treatment of RAW 264.7 and iNOS $^{-/-}$RAW 264.7 cells with either PMA or OZP resulted in comparable changes in $\mathrm{O}_{2}{ }^{\bullet-}$ formation, represented as an increased reduction of cytochrome c (Figures 3(c) and 3(d)). 


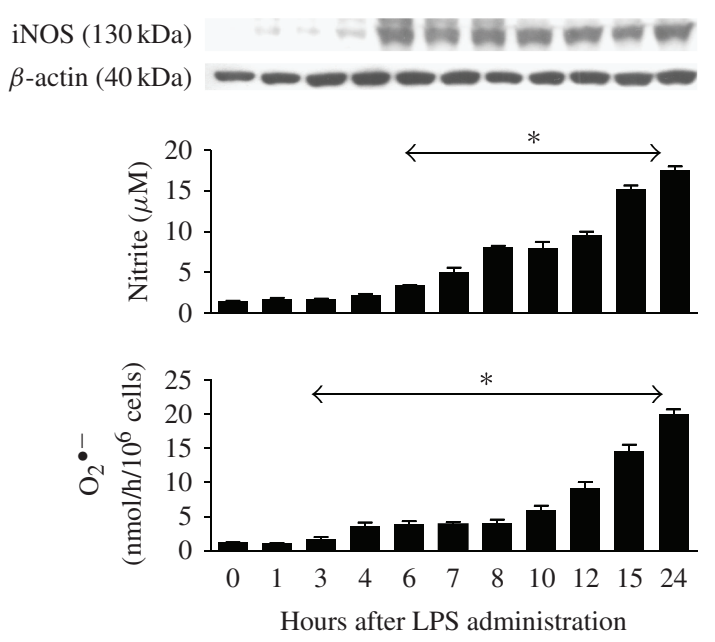

(a)
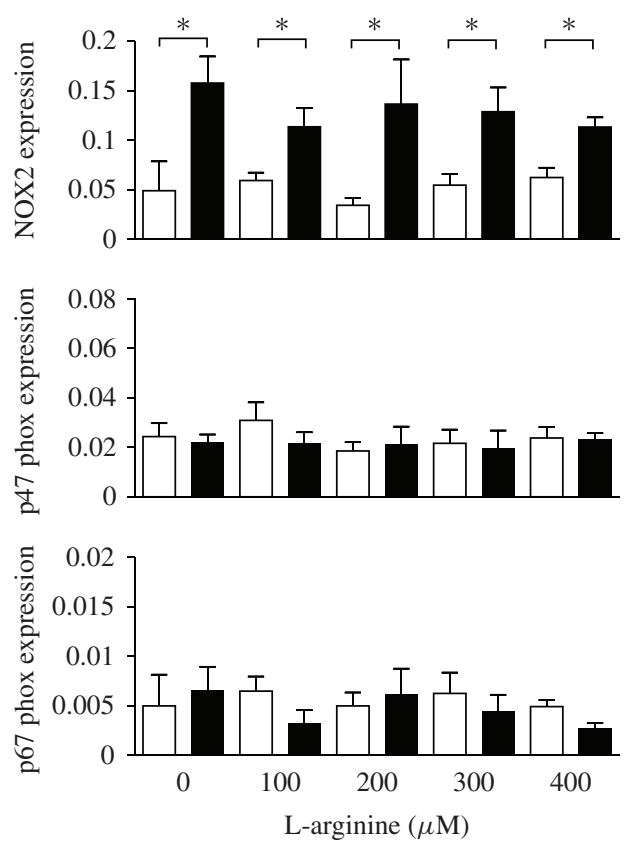

$\square$ Control

- + LPS

(b)

FIGURE 2: iNOS protein expression, nitrite accumulation, $\mathrm{O}_{2}{ }^{\bullet-}$ production and expression of mRNA for NOX2 in RAW 264.7 cells. Cells were incubated in the presence of DMEM media containing $400 \mu \mathrm{M}$ of L-arginine and stimulated with LPS $(50 \mathrm{ng} / \mathrm{mL})$. The expression of iNOS protein in cell lysates, the accumulation of nitrite, and the $\mathrm{O}_{2}{ }^{\bullet-}$ production in cell supernatants (a) were determined at the time points indicated. Results represent means \pm SEM $(n=6)$. (b) For NOX2, p47, and p67phox expression, cells were incubated in DMEM media with different concentrations of L-arginine $(0,100,200,300$, and $400 \mu \mathrm{M})$ and stimulated with LPS $(50 \mathrm{ng} / \mathrm{mL})$ for $4 \mathrm{~h}$. Results represent means $\pm \operatorname{SEM}(n=3) .{ }^{*} P<0.05$.

However, when RAW 264.7 cells were exposed to LPS for $24 \mathrm{~h}$, PMA- and OZP-induced $\mathrm{O}_{2}{ }^{\bullet-}$ production was significantly potentiated, in comparison to iNOS ${ }^{-/-}$RAW 264.7 cells where no such increase was observed. Therefore, we concluded that downregulation of iNOS protein expression did not directly influence the activation of NADPH oxidase.

Increased NOS-dependent $\mathrm{O}_{2}{ }^{\bullet-}$ formation led to a question of whether the amount of nitrotyrosines reflects the production of $\mathrm{ONOO}^{-}$in macrophages. While LPS-treated RAW 264.7, together with RAW 264.7 cells transfected with the negative control plasmid, showed intensive staining for nitrotyrosines, we found no effect for iNOS ${ }^{-/-}$RAW 264.7 cells stimulated with LPS (Figure 4). Interestingly, pretreatment of LPS-stimulated RAW 264.7 cells with L-NAME $(25 \mu \mathrm{M})$ led to a remarkable decrease in the immunostaining for nitrotyrosines (Figure 4(c)).

\subsection{NOS Inhibitors Regulate $\mathrm{NO}$ and $\mathrm{O}_{2}{ }^{\bullet-}$ Production in LPS-Stimulated RAW 264.7 Macrophages}

To verify our hypothesis that an increase in $\mathrm{O}_{2}{ }^{\bullet-}$ formation was associated with the activity of the iNOS enzyme, we used different NOS inhibitors (AMT, $10 \mu \mathrm{M}$; AG, $10 \mu \mathrm{M}$; L-NAME, $25 \mu \mathrm{M}$; LYS, $10 \mu \mathrm{M}$ ). None of the studied drugs was toxic for RAW 264.7 in the concentrations applied (data not shown). First, we tested the effects of inhibitors on iNOS protein expression and iNOS-derived NO production for $24 \mathrm{~h}$. The exposure of LPS-stimulated RAW 264.7 cells to AMT, AG, L-NAME, and LYS caused a significant inhibition of nitrite formation in cell supernatants, while iNOS protein expression was not changed (Figure 5(a)). 


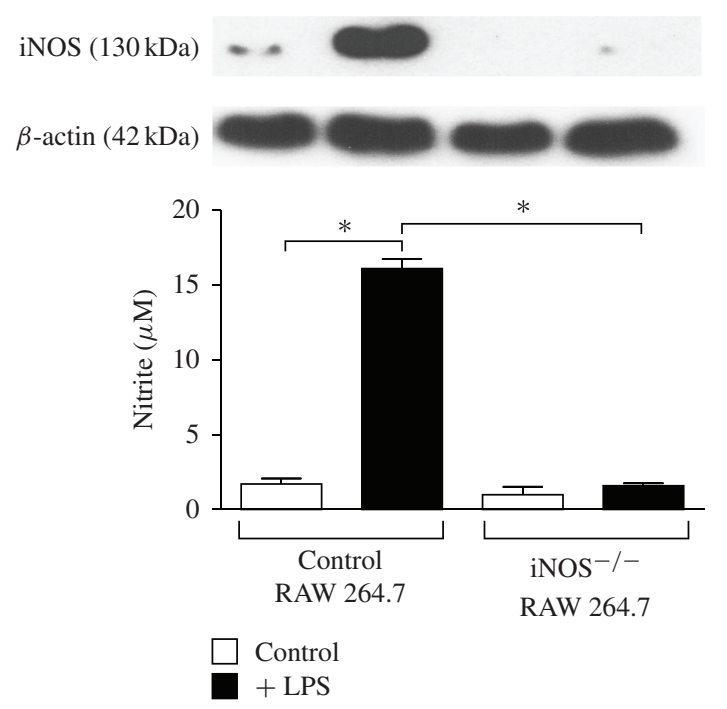

(a)

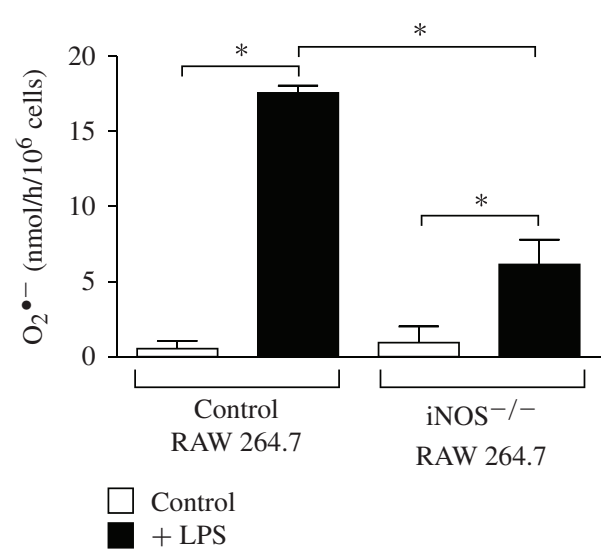

(b)

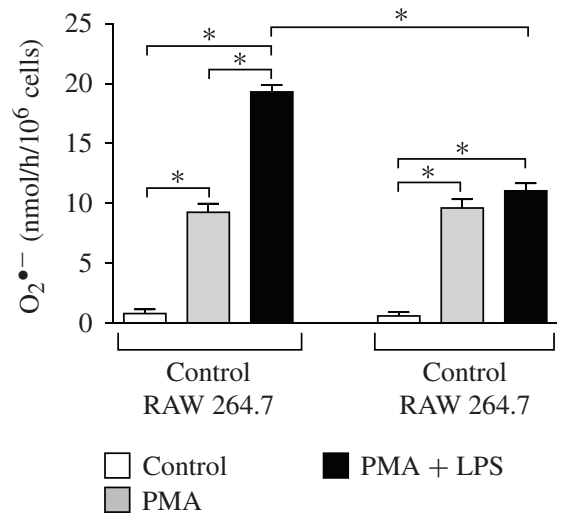

(c)

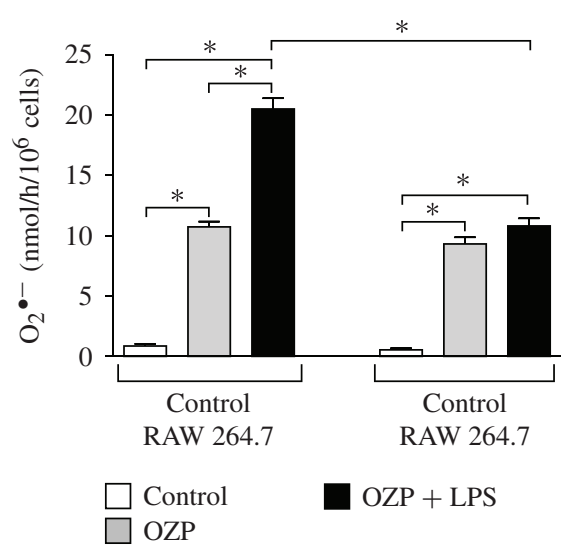

(d)

FIGURE 3: iNOS protein expression, nitrite accumulation, and $\mathrm{O}_{2}{ }^{\bullet-}$ production in RAW 264.7 and iNOS ${ }^{-/-}$ RAW 264.7 cells. Macrophages were stably transfected with shRNA against iNOS and then stimulated with LPS $(50 \mathrm{ng} / \mathrm{mL})$. RAW 264.7 and iNOS ${ }^{-/-}$RAW 264.7 cells were incubated in DMEM media containing $400 \mu \mathrm{M}$ of L-arginine. iNOS protein expression in cell lysates, accumulation of nitrite (a), and $\mathrm{O}_{2}{ }^{\bullet-}$ production in cell supernatants (b) were determined using methods described in Section $2(n=6)$. The $\mathrm{O}_{2}{ }^{\bullet-}$ production was also potentate using (c) PMA and (d) OZP with or without co-administration of LPS $(50 \mathrm{ng} / \mathrm{mL})(n=6) .{ }^{*} P<0.05$.

In control experiments, we found that none of the NOS inhibitors tested were able to induce iNOS protein expression or nitrite accumulation in nonstimulated RAW 264.7 cells incubated in the presence of $400 \mu \mathrm{M}$ L-arginine (data not shown).

To confirm that $\mathrm{O}_{2}{ }^{\bullet-}$ was generated by iNOS, cells were pretreated with NOS inhibitors in the two time-points chosen, according to the results shown in Figure 2. NOS inhibitors administered together with LPS had no effect on $\mathrm{O}_{2}{ }^{\bullet-}$ production within the first $10 \mathrm{~h}$ of incubation (Figure 5(b)). In contrast, after $15 \mathrm{~h}$ of incubation, more than $70 \%$ of $\mathrm{O}_{2}{ }^{--}$production was blocked by all of the NOS inhibitors used (Figure 5(b)). Furthermore, the NOS inhibitors did not affect NADPH-oxidase-derived $\mathrm{O}_{2}{ }^{\bullet-}$ production in PMA- or OZP-activated RAW 264.7 cells incubated with $400 \mu \mathrm{M}$ L-arginine in the absence of LPS (data not shown). 


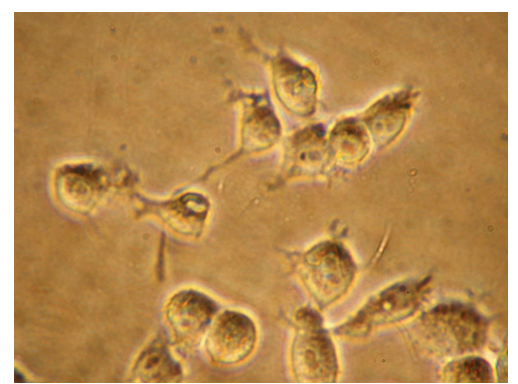

(a)

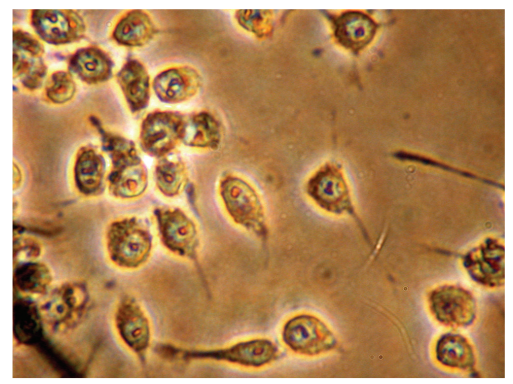

(b)

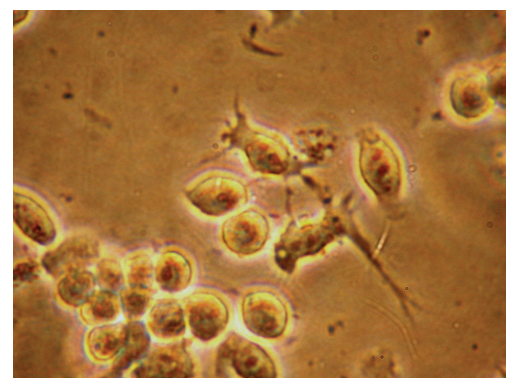

(c)

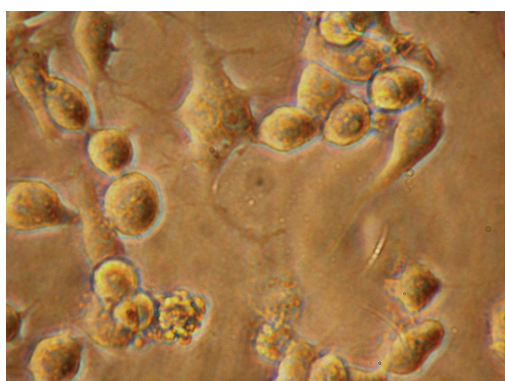

(d)

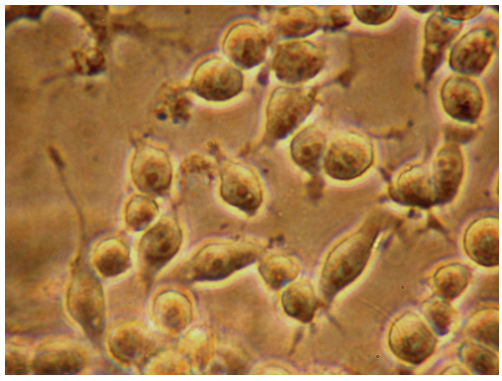

(e)

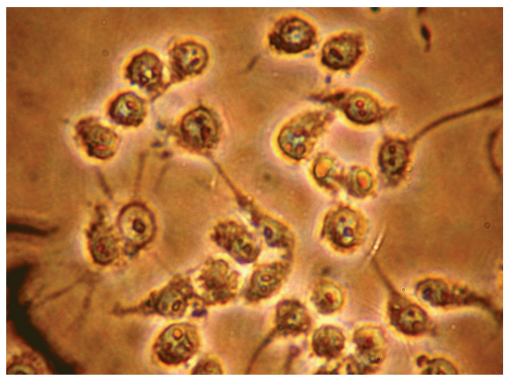

(f)

FIGURE 4: Nitrotyrosine formation in (a) RAW 264.7 cells, (b) RAW 264.7 cells stimulated with LPS, (c) LPS-stimulated RAW 264.7 cells treated with L-NAME $(25 \mu \mathrm{M})$, (d) iNOS ${ }^{-/-}$RAW 264.7 cells, (e) iNOS ${ }^{-/-}$ RAW 264.7 cells stimulated with LPS, and (f) RAW 264.7 cells transfected with negative control plasmid stimulated with LPS. Cells were incubated in the presence of DMEM media supplemented with $400 \mu \mathrm{M}$ of L-arginine.

\section{6. $\mathrm{BH}_{4}$ Is Able to Suppress L-Arginine-Induced $\mathrm{NO}$ and $\mathrm{O}_{2}{ }^{\bullet-}$ Production in RAW 264.7 Cells}

According to data published by Kuzkaya et al. [33], we expected that the uncoupled state of iNOS induced by increased extracellular L-arginine concentrations in LPS-stimulated RAW 264.7 cells could be caused by the decreasing levels of $\mathrm{BH}_{4}$ during the time of the experiments. We added an additional $10 \mu \mathrm{M}$ of $\mathrm{BH}_{4}$ to the cultured media with $400 \mu \mathrm{M}$ L-arginine, along with LPS $(50 \mathrm{ng} / \mathrm{mL})$ stimulation. We showed that the treatment of RAW 264.7 cells with $\mathrm{BH}_{4}$ had no effect on nitrite accumulation and $\mathrm{O}_{2}{ }^{\bullet-}$ production after $10 \mathrm{~h}$ of incubation with LPS (data not shown); however, it was able to partially prevent a massive increase in $\mathrm{O}_{2}{ }^{\bullet-}$ production after $24 \mathrm{~h}$ of incubation with LPS (Figure 6). Accordingly, treatment of RAW 264.7 cells with $\mathrm{BH}_{4}$ caused an increase in nitrite accumulation after $24 \mathrm{~h}$ of cell incubation with LPS, and the iNOS protein expression remained unaffected (Figure 6). 


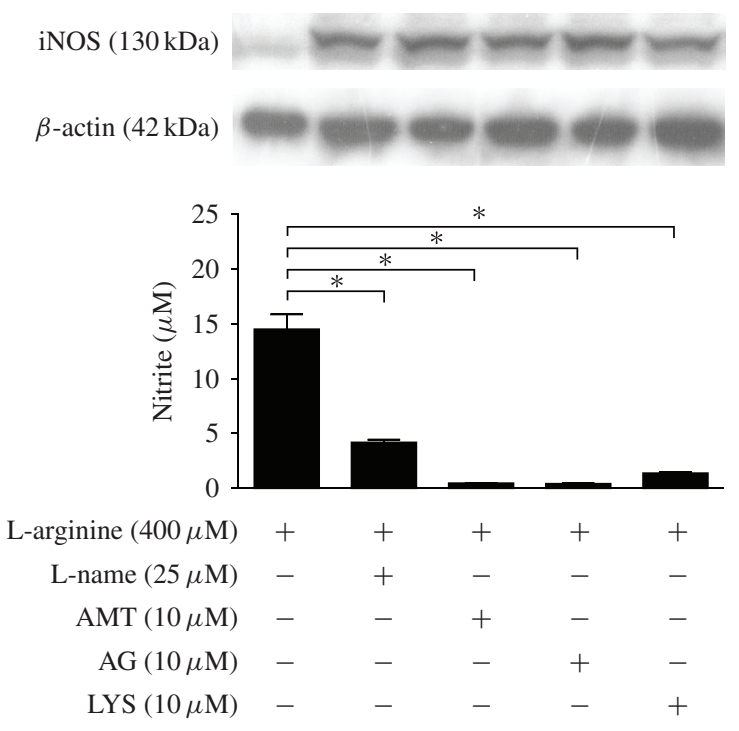

(a)

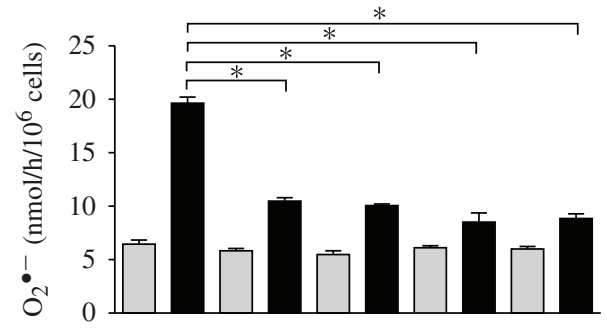

$\mathrm{L}$-arginine $(400 \mu \mathrm{M})+++++++++$

L-name $(25 \mu \mathrm{M})-\quad++-\quad-\quad-\quad$

$\operatorname{AMT}(10 \mu \mathrm{M})--\quad-++---$

$\mathrm{AG}(10 \mu \mathrm{M})-{ }_{-}-c_{-}-++-$

$\operatorname{LYS}(10 \mu \mathrm{M})-c_{-}-c_{-}-c_{-}+$

$\square 10 \mathrm{~h}$ after LPS administration

- $15 \mathrm{~h}$ after LPS administration

(b)

FIGURE 5: NOS inhibitors-dependent regulation of LPS-induced nitrite accumulation and $\mathrm{O}_{2}{ }^{\bullet-}$ production in RAW 264.7 cells stimulated by LPS. Cells were pretreated with NOS inhibitors at the indicated concentrations in the presence of DMEM media containing $400 \mu \mathrm{M}$ of L-arginine. (a) The LPS-induced iNOS protein expression and nitrite accumulation were determined after $24 \mathrm{~h}$ of cell incubation $(n=6)$. (b) The $\mathrm{O}_{2}{ }^{\bullet-}$ production was measured in the presence of DMEM media containing $400 \mu \mathrm{M}$ of L-arginine in two time points: 10 and $15 \mathrm{~h}$ after LPS administration $(n=6) .{ }^{*} P<0.05$.

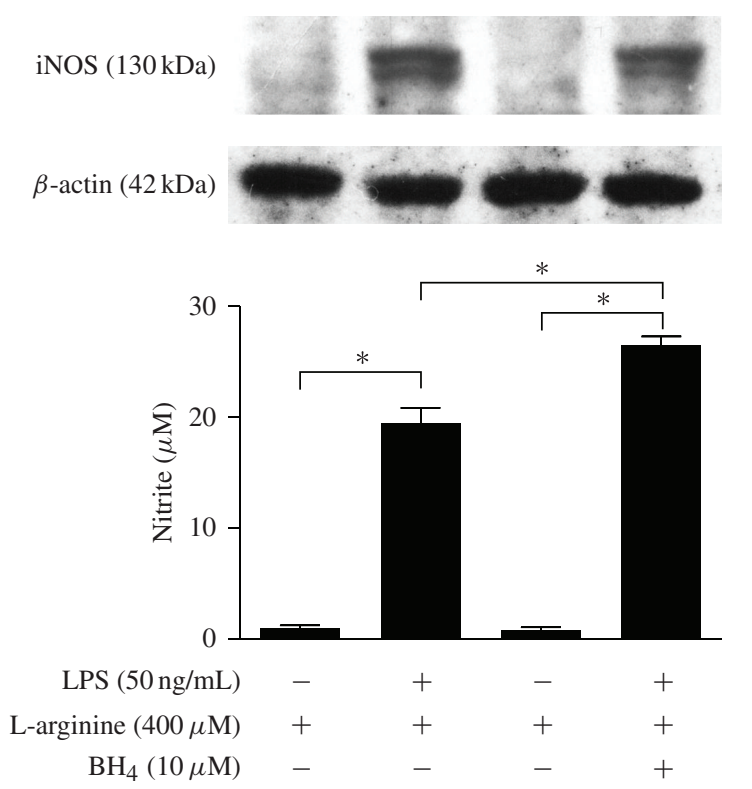

(a)

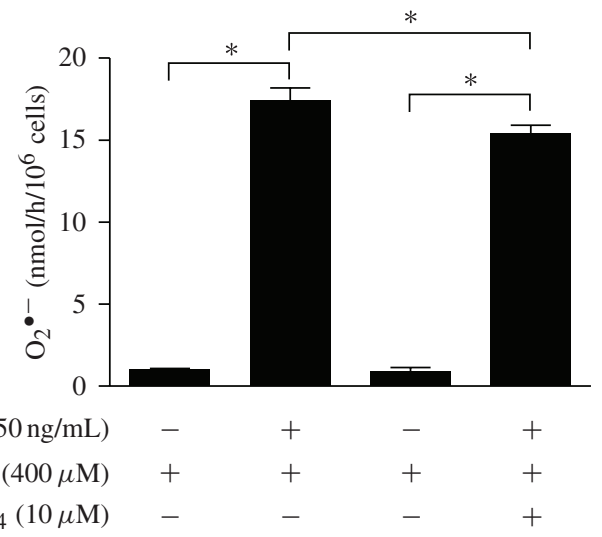

(b)

FIGURE 6: Effect of $\mathrm{BH}_{4}$ on iNOS protein expression, nitrite accumulation, and $\mathrm{O}_{2}{ }^{\bullet-}$ production in RAW 264.7 cells. Cells were incubated with one of the essential NOS cofactors, $\mathrm{BH}_{4}$ in the presence of DMEM media containing $400 \mu \mathrm{M}$ of L-arginine. iNOS protein expression in cell lysates, accumulation of nitrite (a), and $\mathrm{O}_{2}{ }^{\bullet-}$ production in cell supernatants (b) were determined after $24 \mathrm{~h}$ of cell incubation with LPS $(50 \mathrm{ng} / \mathrm{mL})$. Results represent means $\pm \operatorname{SEM}(n=3) .{ }^{*} P<0.05$. 


\section{DISCUSSION}

The current data clearly demonstrate that, beside the regulation of NO production, L-arginine is able to cause a dose- and time-dependent increase in iNOS-derived $\mathrm{O}_{2}{ }^{--}$formation in inflammatory macrophages. Our findings are important with respect to the fact that activation and/or accumulation of macrophages can significantly contribute to the development of inflammation, as well as many disease states that have been shown to be associated with impaired L-arginine metabolism and reduced L-arginine plasma levels (e.g., asthma, pulmonary hypertension, cytstic fibrosis, and renal failure) [34-39].

At present, NADPH oxidase is still considered the main source of $\mathrm{O}_{2}{ }^{\bullet-}$ in inflammatory macrophages [7]. Importantly, it was demonstrated previously that iNOS derived from macrophages is capable of generating functionally important levels of $\mathrm{O}_{2}{ }^{\bullet-}$, in addition to $\mathrm{NO}$ generation under conditions of L-arginine or cofactors depletion $[14,15]$. In contrast, we demonstrated that downregulation of iNOS protein expression leads to a marked reduction of $\mathrm{O}_{2}{ }^{\bullet-}$ production in LPS-stimulated macrophages which are exposed to $400 \mu \mathrm{M}$ of extracellular L-arginine. We found that, under inflammatory conditions, the activity of iNOS enzyme significantly contributes to $\mathrm{O}_{2}{ }^{\bullet-}$ production after 15 hours of incubation of the macrophages with LPS. Importantly, $\mathrm{O}_{2}{ }^{\bullet-}$ production was potentiated by an increased extracellular Larginine concentration. From these observations, several questions arise. (a) Is the increased $\mathrm{O}_{2}{ }^{\bullet-}$ formation associated with changes in NADPH-oxidase expression or activity? (b) Is there any time consistency between $\mathrm{O}_{2}{ }^{\bullet-}$ formation, iNOS protein expression, and iNOS-dependent NO production? (c) Is iNOS probably responsible for increased $\mathrm{O}_{2}{ }^{\bullet-}$ formation?

According to our presented data, we came up with the following possible explanations. First, the NOS inhibitors used in this study could have scavenging properties against ROS and NO. This explanation can be refused, because no scavenging properties of the NOS inhibitors were found in our study. The second alternative is that NOS inhibitors or L-arginine alone may regulate the NADPH oxidasedependent production of $\mathrm{O}_{2}{ }^{\bullet-}$. However, we demonstrated that none of the tested compounds affected $\mathrm{O}_{2}{ }^{\bullet-}$ production from NADPH oxidase in macrophages activated with PMA or OZP in the absence of LPS. The third possibility, that L-arginine regulated the expression of NADPH oxidase in LPS-stimulated macrophages, was also disproved, because the treatment of RAW 264.7 cells with a different extracellular L-arginine concentration had no effect on the NOX2, p47, and p67 mRNA levels. Finally, after the series of experiments with iNOS ${ }^{-/-}$RAW 264.7 macrophages and NOS inhibitors, we proved our assumption that the massive increase in $\mathrm{O}_{2}{ }^{\bullet-}$ formation was very likely caused by macrophage iNOS "uncoupling."

As demonstrated by our study, increased L-arginine concentrations actively contribute to the uncoupled state of iNOS. In contrast, Xia et al. $[14,15]$, in both of their studies, presented that a depletion of cytosolic L-arginine triggered $\mathrm{O}_{2}{ }^{\bullet-}$ generation from macrophage iNOS. Xia et al. [14] also showed that increased $\mathrm{O}_{2}{ }^{\bullet-}$ production can be followed by an NOS-dependent $\mathrm{ONOO}^{-}$formation. They suggest that by coupling L-arginine levels to iNOS protein synthesis, macrophages provide a mechanism for ensuring that iNOS is not expressed in L-arginine-depleted cells and that toxic $\mathrm{O}_{2}{ }^{\bullet-}$ cannot be produced. Based on these data, other clinical studies suggested that limited L-arginine levels can be the significant source of $\mathrm{O}_{2}{ }^{\bullet-}$ - as well as $\mathrm{ONOO}^{-}$-mediated tissue injury $[34,36,37,40]$. Compared to our results, there arises an important question regarding the possibility that the lack of L-arginine is responsible for the macrophage $\mathrm{ONOO}^{-}$ formation. Our data and data published by others [41, 42] implicate that when L-arginine is not available for the iNOS, there is no NO production in stimulated macrophages and thus $\mathrm{NO}$ cannot react with $\mathrm{O}_{2}{ }^{\bullet-}$ to form $\mathrm{ONOO}^{-}$. Therefore, it is questionable if iNOS-derived $\mathrm{ONOO}^{-}$can be responsible for the increased nitrotyrosine formation in macrophages activated in L-arginine-free media as demonstrated by Xia et al. $[14,15]$. Further, $\mathrm{Xia}$ et al. [14] did not detect $\mathrm{O}_{2}{ }^{\bullet-}$ production by macrophages incubated with LPS and IFN- $\gamma$ in the presence of L-arginine supplemented media after $24 \mathrm{~h}$. In contrast, in our experiments, the LPSinduced $\mathrm{O}_{2}{ }^{\bullet-}$ formation could be detected by at least two different methodological approaches as presented above. Interestingly, the only difference between our study and study of Xia et al. [14, 15] is costimulation of macrophages by IFN- $\gamma$. The combination of LPS and IFN- $\gamma$ was used for macrophage stimulation by other authors evaluating $\mathrm{O}_{2}{ }^{\bullet-}$ and $\mathrm{ONOO}^{-}$production by macrophages [42, 43]. Amatore et al. [42] 
described that NO production between $8-18 \mathrm{~h}$ after cell stimulation was slight, and a strong linear increase was then observed for a period of 18-48. Similarly in our experiments, the beginning of gradual NO production was detected after $6 \mathrm{~h}$ of macrophage incubation with LPS. Further, Amatore et al. [42] discovered that macrophages produced $\mathrm{ONOO}^{-}$after $18 \mathrm{~h}$ of incubation with both stimulators, which is in accordance with our data.

We suggest that, during the time of macrophage activation with LPS, L-arginine is consumed by iNOS enzyme, resulting in the production of NO. Because NADPH oxidase in macrophages produces a relevant amount of $\mathrm{O}_{2}{ }^{\bullet-}$ during the first hours after stimulation with LPS, it can easily react with iNOSderived $\mathrm{NO}$ and form highly reactive $\mathrm{ONOO}^{-}$. The more $\mathrm{L}$-arginine that is present, the more $\mathrm{ONOO}^{-}$that is produced. Because $\mathrm{ONOO}^{-}$is a powerful oxidant, it is able to readily oxidize $\mathrm{BH}_{4}$, which can lead to the formation of the $\mathrm{BH}_{3}{ }^{\bullet}$ radical. This phenomenon was already described in endothelial culture cells and vessels, where these conditions caused eNOS uncoupling. Interestingly, after exposure of endothelial cells to $\mathrm{ONOO}^{-}$, eNOS activity could be fully restored by treating the cells with exogenous $\mathrm{BH}_{4}$ [33]. Our hypothesis that the same conditions might play an important role in iNOS uncoupling was supported by the fact that supplementation of $\mathrm{BH}_{4}$ to the cultured and LPS-stimulated macrophages partially prevented an increase in $\mathrm{O}_{2}{ }^{\bullet-}$ formation after prolonged incubation with LPS.

Our findings have some important implications. We have shown that LPS is able to biphasically induce $\mathrm{O}_{2}{ }^{\bullet-}$ production in RAW 264.7 cells. In the first few hours after LPS-stimulation, macrophages produce a relatively small but significant amounts of $\mathrm{O}_{2}{ }^{--}$which should be considered as being formed by activated NADPH oxidase. In the second phase, LPS causes a massive increase in $\mathrm{O}_{2}^{\bullet-}$ production, predominantly due to iNOS uncoupling. More importantly, the second phase of $\mathrm{O}_{2}{ }^{\bullet-}$ production is directly controlled by extracellular L-arginine availability.

In conclusion, the L-arginine availability seems to play a critical role for the immune state of macrophages and there are now two sides of this problematic. One is that a lack of extracellular Larginine is responsible for the attenuation of immune functions associated with the decrease in immune cell proliferation and NO production, which can lead to different pathophysiological states [44-48]. On the other side, supplementation by L-arginine could lead to an increased $\mathrm{O}_{2}{ }^{\bullet-}$, and subsequently an increased ONOO formation that is critical for host defense but might also be deleterious for host cells/tissue.

\section{ACKNOWLEDGMENTS}

The authors thank Lenka Vystrcilova for excellent technical assistance and the BioScience Writters for their expert grammar analysis. This work was conducted under the research plans (AVOZ50040507 and AVOZ50040702) and supported by the Czech Science Foundation (524/08/1753), Masaryk University in Brno (MUNI/C/0886/2010), and European Regional Development Fund-Project FNUSA-ICRC (no. CZ.1.05/1.1.00/02.0123).

\section{REFERENCES}

[1] J. Cohen, "The immunopathogenesis of sepsis," Nature, vol. 420, no. 6917, pp. 885-891, 2002.

[2] A. Chait, Y. H. Chang, J. F. Oram, and J. W. Heinecke, "Lipoprotein-associated inflammatory proteins: markers or mediators of cardiovascular disease?" Journal of Lipid Research, vol. 46, no. 3, pp. 389-403, 2005.

[3] J. C. Pickup and M. A. Crook, "Is type II diabetes mellitus a disease of the innate immune system?" Diabetologia, vol. 41, no. 10, pp. 1241-1248, 1998.

[4] B. Erickson, K. Sperber, and W. H. Frishman, "Toll-like receptors: new therapeutic targets for the treatment of atherosclerosis, acute coronary syndromes, and myocardial failure," Cardiology in Review, vol. 16, no. 6, pp. 273-279, 2008.

[5] V. M. Victor, M. Rocha, and M. de La Fuente, "Immune cells: free radicals and antioxidants in sepsis," International Immunopharmacology, vol. 4, no. 3, pp. 327-347, 2004. 
[6] X. Zhao, K. A. Carnevale, and M. K. Cathcart, "Human monocytes use Rac1, not Rac2, in the NADPH oxidase complex," The Journal of Biological Chemistry, vol. 278, no. 42, pp. 40788-40792, 2003.

[7] M. K. Cathcart, "Regulation of superoxide anion production by NADPH oxidase in monocytes/macrophages. Contribution to atherosclerosis," Arteriosclerosis, Thrombosis, and Vascular Biology, vol. 24, no. 1, pp. 23-28, 2004.

[8] S. Moncada, R. M. J. Palmer, and E. A. Higgs, "Nitric oxide: physiology, pathophysiology, and pharmacology," Pharmacological Reviews, vol. 43, no. 2, pp. 109-142, 1991.

[9] M. F. Linton and S. Fazio, "Macrophages, inflammation, and atherosclerosis," International Journal of Obesity, vol. 27, no. 3, pp. S35-S40, 2003.

[10] M. Guha and N. Mackman, "LPS induction of gene expression in human monocytes," Cellular Signalling, vol. 13, no. 2, pp. 85-94, 2001.

[11] L. Boscá, M. Zeini, P. G. Través, and S. Hortelano, "Nitric oxide and cell viability in inflammatory cells: a role for NO in macrophage function and fate," Toxicology, vol. 208, no. 2, pp. 249-258, 2005.

[12] C. R. Nishida and P. R. Ortiz de Montellano, "Electron transfer and catalytic activity of nitric oxide synthases. Chimeric constructs of the neuronal, inducible, and endothelial isoforms," The Journal of Biological Chemistry, vol. 273, no. 10, pp. 5566-5571, 1998.

[13] P. J. Andrew and B. Mayer, "Enzymatic function of nitric oxide synthases," Cardiovascular Research, vol. 43, no. 3, pp. 521-531, 1999.

[14] Y. Xia, V. L. Dawson, T. M. Dawson, S. H. Snyder, and J. L. Zweier, "Nitric oxide synthase generates Superoxide and nitric oxide in arginine-depleted cells leading to peroxynitrite-mediated cellular injury," Proceedings of the National Academy of Sciences of the United States of America, vol. 93, no. 13, pp. 6770-6774, 1996.

[15] Y. Xia and J. L. Zweier, "Superoxide and peroxynitrite generation from inducible nitric oxide synthase in macrophages," Proceedings of the National Academy of Sciences of the United States of America, vol. 94, no. 13, pp. 6954-6958, 1997.

[16] J. C. Sullivan and J. S. Pollock, "Coupled and uncoupled NOS: separate but equal? Uncoupled NOS in endothelial cells is a critical pathway for intracellular signaling," Circulation Research, vol. 98, no. 6, pp. 717-719, 2006.

[17] N. E. Flynn, C. J. Meininger, T. E. Haynes, and G. Wu, "The metabolic basis of arginine nutrition and pharmacotherapy," Biomedicine and Pharmacotherapy, vol. 56, no. 9, pp. 427-438, 2002.

[18] G. Wu, F. W. Bazer, T. A. Davis et al., "Arginine metabolism and nutrition in growth, health and disease," Amino Acids, vol. 37, no. 1, pp. 153-168, 2009.

[19] P. Li, Y. L. Yin, D. Li, W. S. Kim, and G. Wu, “Amino acids and immune function," British Journal of Nutrition, vol. 98, no. 2, pp. 237-252, 2007.

[20] G. Wu and S. M. Morris Jr., "Arginine metabolism: nitric oxide and beyond," Biochemical Journal, vol. 336, no. 1, pp. 1-17, 1998.

[21] V. Bronte and P. Zanovello, "Regulation of immune responses by L-arginine metabolism," Nature Reviews Immunology, vol. 5, no. 8, pp. 641-654, 2005.

[22] E. Peranzoni, I. Marigo, L. Dolcetti et al., "Role of arginine metabolism in immunity and immunopathology," Immunobiology, vol. 212, no. 9-10, pp. 795-812, 2008.

[23] S. J. Kirk, M. Hurson, M. C. Regan et al., "Arginine stimulates wound healing and immune function in elderly human beings," Surgery, vol. 114, no. 2, pp. 155-160, 1993.

[24] A. Barbul, S. A. Lazarou, D. T. Efron, H. L. Wasserkrug, and G. Efron, "Arginine enhances wound healing and lymphocyte immune responses in humans," Surgery, vol. 108, no. 2, pp. 331-337, 1990.

[25] H. Grasemann, R. Schwiertz, C. Grasemann, U. Vester, K. Racké, and F. Ratjen, "Decreased systemic bioavailability of L-arginine in patients with cystic fibrosis," Respiratory Research, vol. 7, article 87, 2006.

[26] R. Konopka, M. Hýždalová, L. Kubala, and J. Pacherník, "New luminescence-based approach to measurement of luciferase gene expression reporter activity and adenosine triphosphate-based determination of cell viability," Folia Biologica, vol. 56, no. 2, pp. 66-71, 2010.

[27] E. Schwedhelm, V. Xanthakis, R. Maas et al., "Asymmetric dimethylarginine reference intervals determined with liquid chromatography-tandem mass spectrometry: results from the Framingham Offspring Cohort," Clinical Chemistry, vol. 55, no. 8, pp. 1539-1545, 2009. 
[28] M. Pekarova, J. Kralova, L. Kubala et al., "Continuous electrochemical monitoring of nitric oxide production in murine macrophage cell line RAW 264.7," Analytical and Bioanalytical Chemistry, vol. 394, no. 5, pp. 14971504, 2009.

[29] M. Pekarova, J. Kralova, L. Kubala et al., "Carvedilol and adrenergic agonists suppress the lipopolysaccharideinduced no production in raw 264.7 macrophages via the adrenergic receptors," Journal of Physiology and Pharmacology, vol. 60, no. 1, pp. 143-150, 2009.

[30] T. K. Rudolph, V. Rudolph, M. M. Edreira et al., "Nitro-fatty acids reduce atherosclerosis in apolipoprotein E-deficient mice," Arteriosclerosis, Thrombosis, and Vascular Biology, vol. 30, no. 5, pp. 938-945, 2010.

[31] D. Viačková, M. Pekarová, T. Crhák et al., "Redox-sensitive regulation of macrophage-inducible nitric oxide synthase expression in vitro does not correlate with the failure of apocynin to prevent lung inflammation induced by endotoxin," Immunobiology, vol. 216, no. 4, pp. 457-465, 2011.

[32] G. Ambrozova, M. Pekarova, and A. Lojek, "The effect of lipid peroxidation products on reactive oxygen species formation and nitric oxide production in lipopolysaccharide-stimulated RAW 264.7 macrophages," Toxicology in Vitro, vol. 25, no. 1, pp. 145-152, 2011.

[33] N. Kuzkaya, N. Weissmann, D. G. Harrison, and S. Dikalov, "Interactions of peroxynitrite, tetrahydrobiopterin, ascorbic acid, and thiols: implications for uncoupling endothelial nitric-oxide synthase," The Journal of Biological Chemistry, vol. 278, no. 25, pp. 22546-22554, 2003.

[34] N. E. King, M. E. Rothenberg, and N. Zimmermann, "Arginine in asthma and lung inflammation," Journal of Nutrition, vol. 134, no. 10, pp. 2830S-2836S, 2004.

[35] C. R. Morris, M. Poljakovic, L. Lavrisha, L. Machado, F. A. Kuypers, and S. M. Morris, "Decreased arginine bioavailability and increased serum arginase activity in asthma," American Journal of Respiratory and Critical Care Medicine, vol. 170, no. 2, pp. 148-153, 2004.

[36] C. R. Morris, "New strategies for the treatment of pulmonary hypertension in sickle cell disease: the rationale for arginine therapy," Treatments in Respiratory Medicine, vol. 5, no. 1, pp. 31-45, 2006.

[37] N. Gokce, "L-arginine and hypertension," Journal of Nutrition, vol. 134, no. 10, pp. 2807S-2811S, 2004.

[38] H. L. Gornik and M. A. Creager, "Arginine and endothelial and vascular health," Journal of Nutrition, vol. 134, no. 10, pp. 2880S-2887S, 2004.

[39] G. Cherla and E. A. Jaimes, "Role of L-arginine in the pathogenesis and treatment of renal disease," Journal of Nutrition, vol. 134, no. 10, pp. 2801S-2806S, 2004.

[40] T. König, C. Bogdan, and U. Schleicher, "Translational repression of inducible NO synthase in macrophages by 1-arginine depletion is not associated with an increased phosphorylation of eIF2 $\alpha$," Immunobiology, vol. 214, no. 9-10, pp. 822-827, 2009.

[41] S. El-Gayar, H. Thüring-Nahler, J. Pfeilschifter, M. Röllinghoff, and C. Bogdan, "Translational control of inducible nitric oxide synthase by IL-13 and arginine availability in inflammatory macrophages," Journal of Immunology, vol. 171, no. 9, pp. 4561-4568, 2003.

[42] C. Amatore, S. Arbault, C. Bouton, J. C. Drapier, H. Ghandour, and A. C. W. Koh, "Real-time amperometric analysis of reactive oxygen and nitrogen species released by single immunostimulated macrophages," ChemBioChem, vol. 9, no. 9, pp. 1472-1480, 2008.

[43] T. Noda and F. Amano, "Differences in nitric oxide synthase activity in a macrophage-like cell line, RAW264.7 cells, treated with lipopolysaccharide (LPS) in the presence or absence of interferon- $\gamma$ (IFN- $\gamma$ ): possible heterogeneity of iNOS activity," Journal of Biochemistry, vol. 121, no. 1, pp. 38-46, 1997.

[44] P. J. Popovic, H. J. Zeh, and J. B. Ochoa, "Arginine and immunity," Journal of Nutrition, vol. 137, no. 6, pp. 1681S-1686S, 2007.

[45] S. M. Morris, "Arginine metabolism: boundaries of our knowledge," Journal of Nutrition, vol. 137, no. 6, pp. 1602S-1609S, 2007.

[46] D. Coman, J. Yaplito-Lee, and A. Boneh, "New indications and controversies in arginine therapy," Clinical Nutrition, vol. 27, no. 4, pp. 489-496, 2008.

[47] F. Wittmann, N. Prix, S. Mayr et al., "L-arginine improves wound healing after trauma-hemorrhage by increasing collagen synthesis," Journal of Trauma, vol. 59, no. 1, pp. 162-168, 2005. 
[48] G. Wu and C. J. Meininger, “Arginine nutrition and cardiovascular function," Journal of Nutrition, vol. 130, no. 11 , pp. 2626-2629, 2000.

This article should be cited as follows:

Michaela Pekarova, Antonin Lojek, Hana Martiskova, Ondrej Vasicek, Lucia Bino, A. Klinke, D. Lau, Radek Kuchta, Jaroslav Kadlec, Radimir Vrba, and Lukas Kubala, "New Role for L-Arginine in Regulation of Inducible Nitric-Oxide-Synthase-Derived Superoxide Anion Production in Raw 264.7 Macrophages," TheScientificWorldJOURNAL, vol. 11, pp. 2443-2457, 2011. 


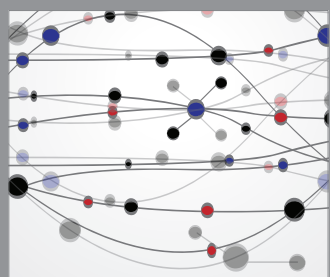

The Scientific World Journal
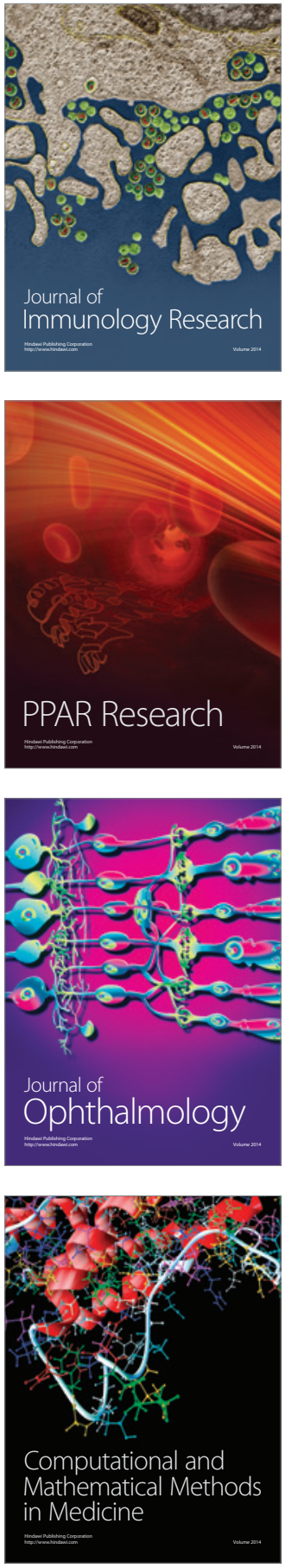

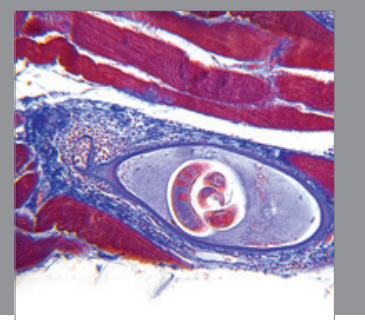

Gastroenterology

Research and Practice
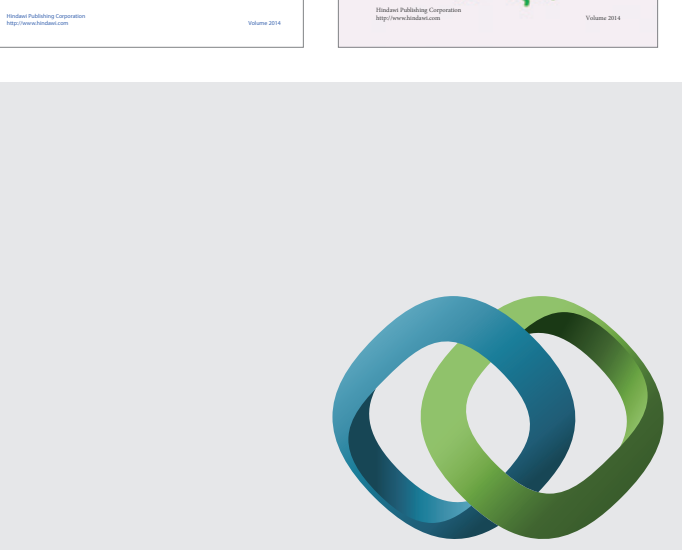

\section{Hindawi}

Submit your manuscripts at

http://www.hindawi.com
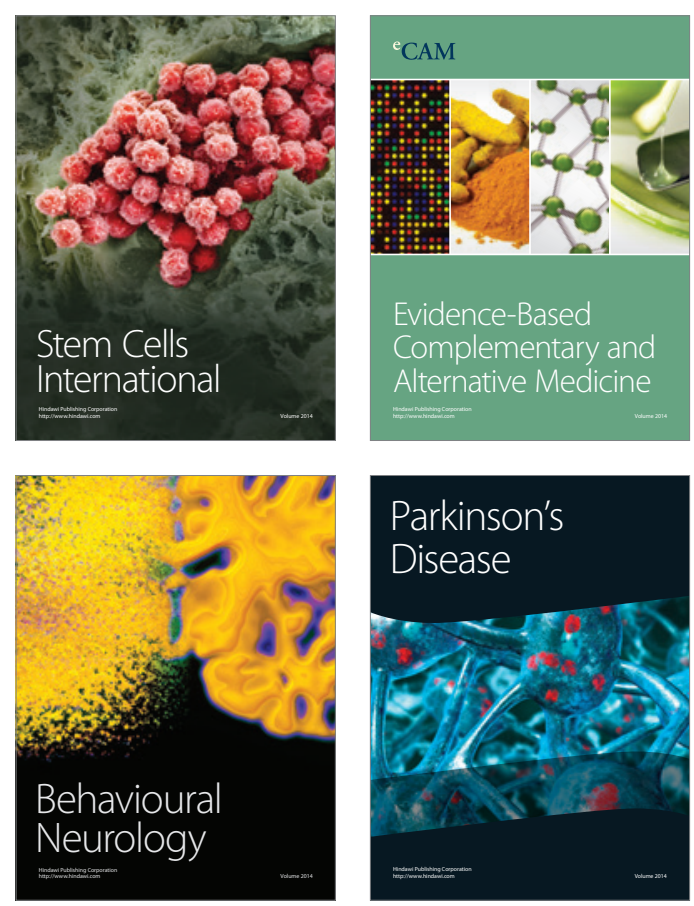

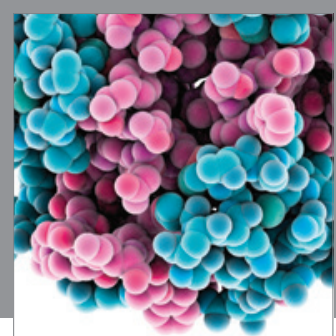

Journal of
Diabetes Research

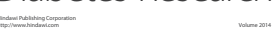

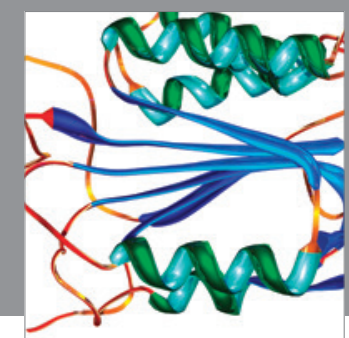

Disease Markers
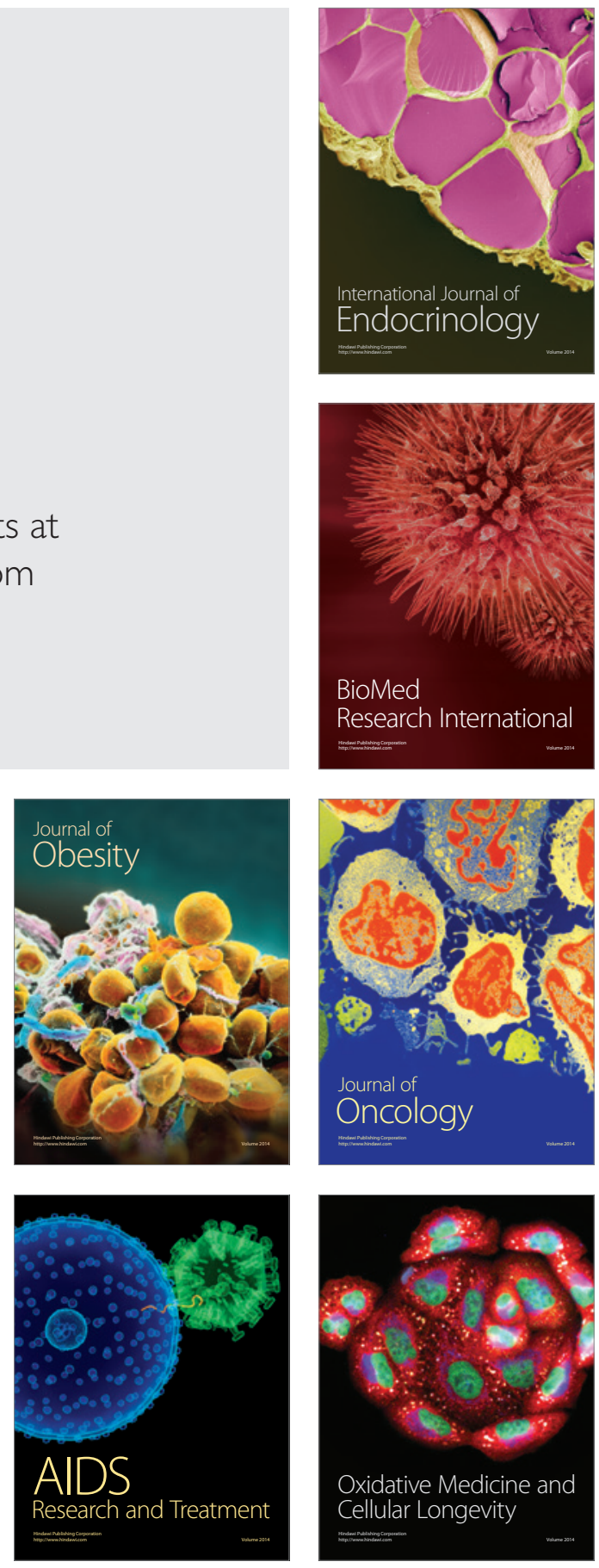